\title{
Mineralogical Characterization and Beneficiation Studies of Pyrophyllite from Orissa, India
}

\author{
B. Das and J.K. Mohanty \\ Institute of Minerals and Materials Technology \\ (Council of Scientific and Industrial Research) \\ Bhubaneswar-751013, Orissa. \\ Contact: bdas@immt.res.in and jkmohanty@immt.res.in
}

\begin{abstract}
Mineralogical and chemical analyses of three textural varieties of pyrophyllite samples collected from Baliadihi mine of Keonjhar district, Orissa, India are investigated. Mineralogically they consist of quartz, pyrophyllite, altered feldspar as major minerals and muscovite, chlorite, tourmaline, hematite etc. as minor minerals. The samples exhibit compositional variation of $\mathrm{SiO}_{2} 65.56-71.66 \%, \mathrm{Al}_{2} \mathrm{O}_{3}$ 18.79-22.94\%, $\mathrm{FeO} 1.13-1.68 \%$ and alkalis 3.24 to $6 \%$. Beneficiation studies using flotation technique has indicated that silica can be reduced with concomitant increase in alumina and brightness from a raw pyrophyllite sample which can be suitable for refractory purposes.
\end{abstract}

Keywords: Pyrophyllite, characterisation, flotation, brightness

\section{INTRODUCTION}

Pyrophyllite is one of the most important industrial minerals having manifold uses. Like talc, it is used in porcelain, building materials, fire-resistant material, insecticide, textiles, detergents, cosmetics and the filler for rubberising, papermaking, painting etc. Due to some intrinsic properties such as chemical inertness, high melting point and dielectric constant and low electrical conductivity, pyrophyllite is useful in ceramic and refractory applications. It can be used as refractory raw material because of low thermal conductivity and coefficient of expansion, hot load deformation, excellent reheat stability, corrosion resistance and low heat shrinkage. It requires lower firing temperature that reduces shrinking and cracking and improves thermal shock resistance. Massive to coarsely foliated compact pyrophyllite is suitable for refractory where as finely foliated variety is used in ceramic and other industries. The massive variety which is marked as grade A is used as wares for stacking graphite and solvent for the manufacture of synthetic diamond. 
Finished product of pyrophyllite has a high degree of vitrification and good mechanical resistance. It is also used as filler in plastics and rubber, wallboard, paint, adhesives and roofing resins. Pyrophyllite has a neutral $\mathrm{pH}$ and is inert, nonabrasive with good flowability allowing it to be used as a diluent, extender, carrier for liquids, fungicides, herbicides and fertilisers. It is used as additive in lubricants and foundry mould coatings.

Pyrophyllite is an early stage metamorphic mineral and is actually quite common although usually not very abundant as good mineral specimens. It is found as a constituent of slate, phyllite, schist and other early stage metamorphic rocks. The specifications recommended for various uses of pyrophyllite are shown in Table-1.

Table. 1 : Specification of pyrophyllite for different industries.

\begin{tabular}{|l|l|l|l|l|l|l|l|}
\hline Use & Oxide & $\mathrm{Wt} \%$ & $\begin{array}{l}\text { Min. } \\
\text { /Max. }\end{array}$ & Use & Oxide & Wt\% & $\begin{array}{l}\text { Min./ } \\
\text { Max. }\end{array}$ \\
\hline $\begin{array}{l}\text { Refrac } \\
\text { tory }\end{array}$ & $\mathrm{Al}_{2} \mathrm{O}_{3}$ & 28 & Min. & Ceramic & $\mathrm{Al}_{2} \mathrm{O}_{3}$ & 25 & Min. \\
\hline & $\mathrm{SiO}_{2}$ & 60 & Max. & & $\mathrm{SiO}_{2}$ & 60 & Min. \\
\hline & $\mathrm{Alkalis}$ & $<0.5$ & & & $\mathrm{Fe}_{2} \mathrm{O}_{3}$ & 1 & Max. \\
\hline & PCE & 28 & Min. & & $\mathrm{TiO}_{2}$ & 1 & Max. \\
\hline Paper & LOI & 3 & Max. & & $\mathrm{MgO}$ & 0.5 & Max. \\
\hline & $+300 \#$ & 15 & & & $\mathrm{CaO}_{3}$ & 0.5 & Max. \\
\hline & Moisture & 3 & Min. & Insecticide & $\mathrm{Fe}_{2} \mathrm{O}_{3}$ & 1.5 & Max. \\
\hline & CaO & 1 & Max. & & LOI & 6 & Max. \\
\hline & Brightness & $>80$ & & & $\begin{array}{l}\text { Acid } \\
\text { Insolubles }\end{array}$ & 97 & Min. \\
\hline
\end{tabular}

Pyrophyllite is a member of phyllosilicates or leaf silicates, which have a sheet-like structure. The phyllosilicates form stacks of silicate layers that are composed of $\mathrm{SiO}_{4}$ tetrahedrons. The sheets are not directly linked above or below to the next silicate sheets. In Pyrophyllite, two silicate layers are sandwiched between gibbsite layers. Gibbsite is composed of octahedral coordinated aluminium surrounded by six hydroxides. The gibbsite layer $(\mathrm{G})$ in pyrophyllite is identical to gibbsite structure except that four of the hydroxides are replaced by four oxygens from the silicate layers $(\mathrm{S})$. The overall structure of pyrophyllite can be imagined as stacked S-G-S sandwiches. The bonding between these sandwiches is nearly nonexistent and gives rise to softness and perfect cleavage in pyrophyllite. It has been reported that the interlayer bonding forces between $\left[\mathrm{SiO}_{4}\right]$ and $\left[\mathrm{AlO}_{3}(\mathrm{OH})_{3}\right]^{6-}$ are Van der Waals. Due to this weak force the surface of pyrophyllite is electrically neutral which give rise to a moderate degree of natural floatability [1].

Pyrophyllite is a secondary mineral mostly derived from alteration of feldspar and has a chemical formula of $\left(\mathrm{Al}_{2} \mathrm{O}_{3} \mathrm{Si}_{4} \mathrm{O}_{10}\right) \mathrm{OH}$. Though silica and alumina are the major constituents, the common impurities are $\mathrm{FeO}, \mathrm{CaO}, \mathrm{MgO}, \mathrm{TiO}_{2}$ and alkalis. It occurs in all shades of 
colour, particularly white, light grey, greenish pink, brown, buff and green depending upon the presence of coloured minerals. Pyrophyllite is identical in physical properties to talc. The two are isomorphous. Talc has magnesium instead of aluminium and is basically indistinguishable from pyrophyllite without a chemical test for aluminium. It does not flux when heated making it an efficient refractory material.

\section{MODE OF OCCURRENCE}

The pyrophyllite reserve of Orissa is around 10 million tonnes [2] and Orissa is a major producer of pyrophyllite. Pyrophyllite occurs as small and large discontinuous lensoidal to pockety outcrops spatially associated with Singhbhum /Bonai Granite. The mineral bodies are mostly confined to hill slopes capped by Dhanjori quartzite of variable thickness. Sometimes they are also seen forming isolated hills/knolls with/without quartzite capping. Economic deposits of pyrophyllite in Keonjhar district, Orissa, India occur adjacent to the western hillock stretching over a strike length of $90 \mathrm{~km}$ from Rebna-Palaspal in south to Dhobakuchuda-Balabhadrapur in the north more or less along a N-S trending lineament. The main deposits are at Jaipur, Dhobakuchuda, Balabhadrapur, Anjor, Baliadihi, Madrangajodi, Dalimpur, Nithigotha, Buriadihi, Sidhamath, Sarasposi, Ukchabeda, Roduna, Bolaniposi, Rampakot, Rebna and Palaspal, all in Keonjhar district. Occurrences are also reported near Manada, Joshipur and foothills of Similpal in Mayurbhanj district and Lahunipada in Sundergarh district. Regular mining activity, mostly manual at a few places are going on. Pyrophyllite usually occurs in the form of quartz pyrophyllite schist containing pockets of massive granular pyrophyllite. The pyrophyllite is of lower grade in the lower level and high grade in the upper level.

A comparison of low and high grade pyrophyllite is given in Table 2.

Table 2. Characteristics of high and low grade pyrophyllites.

\begin{tabular}{|c|c|c|}
\hline Characteristics & High grade & Low grade \\
\hline \multicolumn{3}{|c|}{ Physical Characteristics } \\
\hline Colour & Milky white & Greyish white \\
\hline Texture & Massive to Coarse schistose & $\begin{array}{l}\text { Schistose } \\
\text { (medium to fine grained) }\end{array}$ \\
\hline Feel & Strongly soapy & Moderately soapy \\
\hline Hardness & $1.5-2$ & $2-3$ \\
\hline \multicolumn{3}{|c|}{ Chemical Characteristics } \\
\hline $\mathrm{Al}_{2} \mathrm{O}_{3}$ & $21.66-24.80$ & $19.07-21.03$ \\
\hline $\mathrm{SiO}_{2}$ & 69.56-73.08 & $74.14-75.82$ \\
\hline $\mathrm{Fe}_{2} \mathrm{O}_{3}$ & $0.18-0.50$ & $0.23-0.37$ \\
\hline $\mathrm{TiO}_{2}$ & $0.16-0.32$ & $0.20-0.30$ \\
\hline $\mathrm{CaO}$ & $0.28-0.56$ & $0.28-0.42$ \\
\hline $\mathrm{MgO}$ & $0-0.20$ & Nil \\
\hline $\mathrm{Na}_{2} \mathrm{O}$ & $0.38-2.36$ & $0.4-0.51$ \\
\hline $\mathrm{K}_{2} \mathrm{O}$ & $0.04-0.30$ & $0.06-0.12$ \\
\hline
\end{tabular}




\begin{tabular}{|l|l|l|}
\hline LOI & $2.86-3.90$ & $3.46-3.66$ \\
\hline Mineralogical Characteristics & \multicolumn{2}{|l|}{} \\
\hline \% Pyrophyllite & $>95$ & 90 \\
\hline \%Quartz & $<2$ & $7-10$ \\
\hline \%Tourmaline & Trace & Trace \\
\hline \%Opaque & Trace & Trace \\
\hline
\end{tabular}

\section{MATERIALS AND METHODS}

The pyrophyllite samples of different varieties were collected from a working mine at Baliadihi, Keonjhar district of Orissa. Each sample was thoroughly mixed and a well representative sample was drawn in each case for detail characterisation and beneficiation studies. The run off mine samples were crushed and ground in the laboratory ball mill to below $75 \mu \mathrm{m}$ size in which the beneficiation studies were carried out. Chemical analysis of different size fractions indicates that aluminium values are enriched in the finer fractions. The grade of aluminium increases with decrease in particle size. Major and minor elements of the bulk samples and the flotation products were analysed by X-ray florescence technique.

Microscopic and X-ray diffraction studies were carried out for the identification of mineral phases present in the samples. A Leitz orthoplan transmitted light microscope was used for the microscopic studies. The XRD study was carried out by automatic Philips PW 1750 unit using a scanning speed of $2 \% \mathrm{~min}$. in the range of $2 \varnothing$ from 10 to $70^{\circ}$. The brightness of the raw pyrophyllite and pyrophyllite roasted at $1200^{\circ} \mathrm{C}$ was measured by reflectance meter taking $\mathrm{MgO}$ powder as standard (100 units).

Denver, $\mathrm{D}_{12}$ subaeration flotation machine with one litre capacity was used for batch flotation studies. Dodecylamine, a cationic reagent was used as the collector for the flotation of pyrophyllite. All the flotation studies were carried out after stage crushing in jaw and roll crusher followed by grinding in the laboratory ball mill. The flotation tests were carried out after conditioning the sample with required amount of reagents for a predetermined time. The agitation intensity, the pulp density and $\mathrm{pH}$ were controlled during the experiments. $\mathrm{pH}$ of the slurry was maintained before the addition of the collector and monitored through out the experiment. Dilute $\mathrm{NaOH}$ or $\mathrm{HCl}$ was added to regulate the $\mathrm{pH}$ value. All the flotation tests were carried out at a fixed pulp density. The concentrates and tailings were collected separately, dried, weighed and analysed for different constituents to assess the product quality.

\section{MINERALOGY}

Pyrophyllite is a product of hydrothermal alteration of granite. The mineralogy of pyrophyllite bearing rocks is almost similar to granite/altered granite. The results of mineralogical study of different varieties of pyrophyllite bearing rocks carried out under microscope are as follows. 


\subsection{Granular Variety}

This variety exhibits a granular texture (Fig. 1). Irregular and anhedral coarse grains of quartz and subhedral grains of altered feldspars are embedded in a matrix of pyrophyllite. Comparatively coarse flakes constitute the matrix whereas the flakes of pyrophyllite within altered feldspars are very fine grained. Finely pyrophyllitised subhedral grains are pseudomorphs after feldspar. Orthoclase as relics within pyrophyllite is less altered. Both quartz and feldspar grains are veined by pyrophyllite. Minor amounts of secondary biotite, tourmaline, opaques and rutile are present. Pyrophyllitised feldspar grains near the margin are rimmed by coarser muscovite. The mineral assemblage of granular variety can be put as pyrophyllite + quartz + altered feldspar + muscovite + tourmaline + opaques.

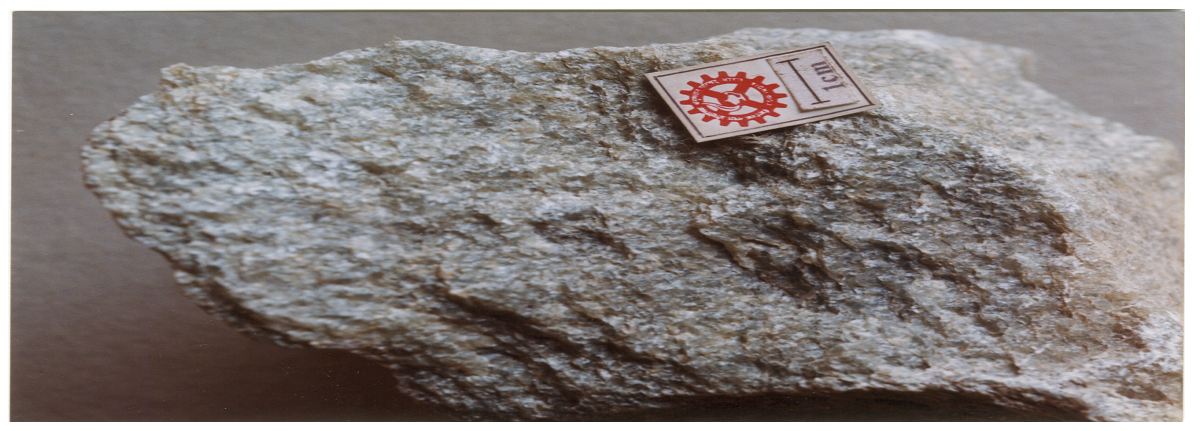

Fig. 1. Irregular and anhedral coarse grains of quartz and subhedral grains of altered feldspars are embedded in a matrix of pyrophyllite.

\subsection{Schistose Variety}

Minerals constituting the rock are pyrophyllite, quartz and muscovite \pm chlorite. Opaques are common in form of minute prismatic, skeletal and dusty forms. Accessory minerals include secondary biotite, illite (yellowish coloured minute prismoids interfolial to pyrophyllite), rutile (brownish/reddish coloured small euhedra and subhedra showing thick borders), anatase (subhedral bluish coloured), tourmaline (prismatic) and sphene (rhombic shaped). Pyrophyllite as coarse to medium flakes/laminae along with flaky muscovite imparts pronounced schistosity (Fig.2). Quartz showing undulose extinction occurs as dilated, elongated eye shaped, granulated/fractured grains in interfolial planes of flaky minerals. Quartz grains when drawn elongated are aligned subparallel to the schistosity plane. Their borders are denticulated due to replacement by pyrophyllite. 


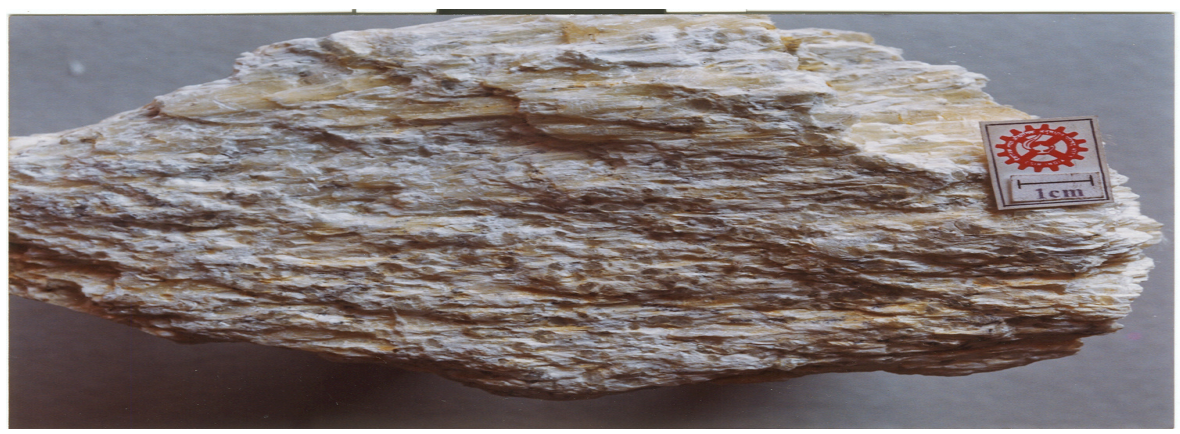

Fig. 2. Pyrophyllite as coarse to medium flakes/laminae along with flaky muscovite imparts pronounced schistosity.

\subsection{Slaty Variety}

It is a cryptoscaly variety that forms a large bulk of the valley deposit, being concordant with the schistose variety. Although in naked eye, very fine lamellae are indistinct, under microscope cryptoscaly flakes are clearly visible. It is a pyrophyllite + muscovite + quartz + tourmaline \pm chlorite in which pyrophyllite and muscovite constitute around $90 \%$ of the bulk. Secondary biotite, illite, rutile and opaques are present in minor proportions. Pyrophyllite and muscovite are concordantly arranged to impart fine laminations that are megascopically identified as crude slaty cleavages (Fig.3). They are characterised by wavy extinction.

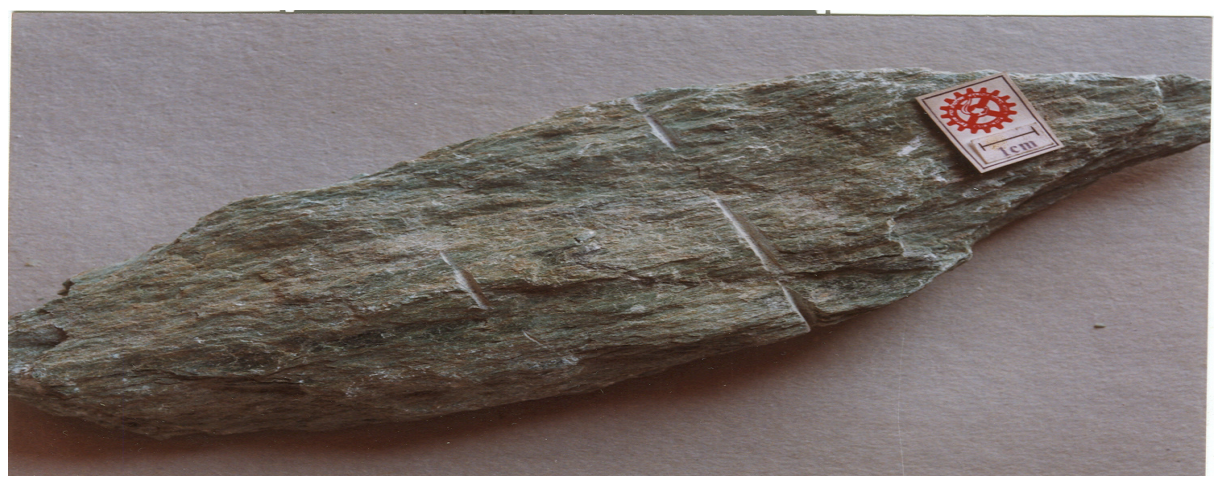

Fig. 3. Pyrophyllite and muscovite are concordantly arranged to impart fine laminations that are megascopically identified as crude slaty cleavages.

The modal analysis data of three different petrographic varieties of pyrophyllite are presented in Table 3.

Table 3. Modal analysis data of different petrographic varieties of pyrophyllite.

\begin{tabular}{|l|l|l|l|l|l|l|}
\hline Variety & Pyrophyllite & Quartz & Muscovite & Chlorite & Tourmaline & Opaque \\
\hline Granular & $49-65$ & $17-28$ & $7-9$ & Nil & $1-2.6$ & $0.54-2$ \\
\hline Schistose & $56-61$ & $17-26$ & $8-18$ & $2-10$ & $0.25-1$ & $2-3$ \\
\hline Slaty & $65-68$ & $6-8$ & $15-19$ & 2 & $0.23-0.46$ & $3-6$ \\
\hline
\end{tabular}


Petrographically the pyrophyllite bearing rocks are divisible into three major varieties. Major minerals are pyrophyllite, quartz, muscovite with/without chlorite and tourmaline. Minor to trace amounts of rutile, tourmaline, anatase, sphene, illite and kaolinite are present. Modal analysis data reveal that slaty variety contains high amount of pyrophyllite compared to the granular and schistose varieties. This variety also contains more muscovite (15-19\%) and lesser amount of quartz compared to the other two varieties. The granular variety contains more free quartz that may be easily separated from pyrophyllite. Hence this sample was taken for beneficiation study.

\subsection{Brightness}

Brightness of pyrophyllite plays a key role in deciding its utility and value in different industries. The brightness data of the different varieties are shown in Table 4.

Table 4. Brightness of different varieties of pyrophyllite .

\begin{tabular}{|c|c|c|c|}
\hline Samples & Sp.Gr. & \multicolumn{2}{|c|}{ Brightness } \\
\cline { 3 - 4 } & & Room temp & $1200^{\circ} \mathrm{C}$ \\
\hline Granular & 1.62 & 69 & 80 \\
\hline Schistose & 1.60 & 62 & 72 \\
\hline Slaty & 1.61 & 54 & 66 \\
\hline
\end{tabular}

From the study it is observed that by only firing the powder sample at $1200^{\circ} \mathrm{C}$, there is an increase in the brightness. The brightness of the sample depends on the impurity content in the sample. The presence of quartz and coloured minerals such as iron-oxide-hydroxide, opaques, chlorite, and micaceous minerals decreases the overall brightness of the material. So it is important to reduce the coloured minerals and opaques from the raw sample to enhance the brightness of the material.

\subsection{Chemical Composition}

As pyrophyllite is derived from granitic rocks by metasomatism/ low temperature hydrothermal activity, the chemical composition of pyrophyllite is broadly similar to granitic composition with slight variation depending on the degree of hydrothermal alteration. The chemical analyses of the different varieties are given in Table 5.

Table 5. Major element composition (wt\%) of pyrophyllite types $(\mathrm{N}=5)$.

\begin{tabular}{|l|l|l|l|l|l|l|l|l|}
\hline Type & $\mathrm{SiO}_{2}$ & $\mathrm{Al}_{2} \mathrm{O}_{3}$ & $\mathrm{FeO}$ & $\mathrm{CaO}$ & $\mathrm{MgO}$ & $\mathrm{Na}_{2} \mathrm{O}$ & $\mathrm{K}_{2} \mathrm{O}$ & LOI \\
\hline Granular & 67.88 & 20.87 & 1.59 & 0.64 & 0.67 & 0.96 & 3.98 & 2.66 \\
\hline Schistose & 67.12 & 19.32 & 1.68 & 1.55 & 1.50 & 1.40 & 4.60 & 2.20 \\
\hline Slaty & 65.74 & 22.83 & 1.46 & 1.55 & 0.86 & 0.90 & 4.27 & 2.02 \\
\hline
\end{tabular}

$\mathrm{N}=$ No of samples from each variety 
From the above table it is observed that silica and alumina are two major constituents of pyrophyllite. The samples contain 19 to $23 \% \mathrm{Al}_{2} \mathrm{O}_{3}$ and 65 to $68 \% \mathrm{SiO}_{2}$ and have 2 to $3 \%$ LOI. Potassium is more than sodium indicating that it is derived from K-bearing feldspars especially orthoclase. $\mathrm{FeO}, \mathrm{CaO}$ and $\mathrm{MgO}$ are present in minor to trace amount.

\section{BENEFICIATION STUDIES}

In order to meet the specifications of various industries the quality and brightness of pyrophyllite has to be upgraded by removing the undesirable and coloured minerals. From the three varieties of pyrophyllite, based on petrographic study (modal analysis), the granular variety was found suitable for beneficiation. Out of the various beneficiation methods, flotation may be an ideal one as other methods such as gravity and magnetic methods are unsuitable because (i) the density difference between the pyrophyllite and quartz is not significant to attempt gravity separation and (ii) quantum of the magnetic materials in the sample is very less.

\subsection{Flotation Studies}

The basic objective of beneficiation studies is to investigate the response of flotation performance for the recovery of pyrophyllite from the associated minerals. The collector used for flotation studies is dodecylamine due to its satisfactory collecting power for the aluminosilicate minerals at certain $\mathrm{pH}$ ranges. More over the crystal structure analysis of the pyrophyllite shows that it has most cleavable planes and due to its lower aluminium silica ratio responds more favourably to cationic collectors (1). The cationic flotation has been extensively studied and practised in kaolinite purification and iron ore processing [3, 4]. The surface properties and flotation behaviour of kaolinite, illite and pyrophyllite using dodecylamine as a collector have been investigated extensively [5]. SEM studies have indicated that pyrophyllite takes the thin slice shape without any pores and hence taking the same reagent could easily float $96 \%$ of pyrophyllite. The collector molecules may be adsorbed both on internal and external surface leading to better flotation of the pyrophyllite compares to illite and kaolinite. Similarly flotation of pyrophyllite using N-dodecyl-1 and 3diaminoprpopane was carried out where the recovery of the mineral was found to be more than $80 \%$ [6]. The effect of dry grinding on flotation recovery of pyrophyllite was also studied using an alcohol type frother. It was observed that dry grinding for longer duration negatively affects the pyrophyllite flotation [7]. The complete chemical analysis of the granular variety pyrophyllite sample for flotation study is shown in Table 6.

Table 6. Chemical analysis of the pyrophyllite sample.

\begin{tabular}{|l|l|l|l|}
\hline Oxide & $\mathrm{Wt} \%$ & Oxide & $\mathrm{Wt} \%$ \\
\hline $\mathrm{SiO}_{2}$ & 63.62 & $\mathrm{~K}_{2} \mathrm{O}$ & 5.47 \\
\hline $\mathrm{Al}_{2} \mathrm{O}_{3}$ & 21.36 & $\mathrm{Na}_{2} \mathrm{O}$ & 0.10 \\
\hline $\mathrm{Fe}_{2} \mathrm{O}_{3}$ & 0.26 & $\mathrm{TiO}_{2}$ & 0.12 \\
\hline $\mathrm{MgO}$ & 0.03 & $\mathrm{P}_{2} \mathrm{O}_{5}$ & 0.01 \\
\hline $\mathrm{CaO}$ & 0.05 & & \\
\hline
\end{tabular}


The sample contains 21.4\% $\mathrm{Al}_{2} \mathrm{O}_{3}, 63.6 \% \quad \mathrm{SiO}_{2}$ and $5.5 \% \mathrm{~K}_{2} \mathrm{O}$ as the major constituents. Besides that, it also contains traces of $\mathrm{CaO}, \mathrm{MgO}, \mathrm{TiO}_{2}$ and $\mathrm{Fe}_{2} \mathrm{O}_{3}$. The sample is greyish white in colour. The results of flotation studies as a function of $\mathrm{pH}$ are shown in Fig. 4. It has been seen that the collector shows a satisfactory collecting power for the pyrophyllite mineral. The aluminosilicate mineral exhibits a better flotatbility in a mild acidic medium of around $\mathrm{pH}$ 4.5. At a reagent concentration of 100 gms/tonne an alumina concentration of $29.5 \%$ with $54 \%$ recovery could be obtained. The flotability decreases at alkaline $\mathrm{pH}$. The relationship between the contact angle and zeta potential for flotation point of view of pyrophyllite is well studied [1]. The contact angle of water on pyrophyllite is $>40^{\circ}$ over a wide $\mathrm{pH}$ range from 2-12. The contact angle has increased to $>65^{\circ}$ when treated with $0.2 \mathrm{mM}$ DDA solution suggesting the flotability of this mineral. The zeta potential of pyrophyllite mineral suggests that it exhibits iep at $\mathrm{pH} 2.4$ [8]. Below this iep, the aluminosilicate mineral is highly negative. Hence when dodecylamine is introduced into the pulp at the acidic $\mathrm{pH}$, it may be attracted due to electrostatic force at the mineral surface. In the alkaline $\mathrm{pH}$ range the flotatbility of pyrophyllite mineral may be due to precipitation of DDA molecules and weak hydrogen bonding between $\mathrm{NH}_{2}$ group and aluminosilicate resulting in a decrease in recovery. A typical analysis of the flotation products is given in Table -7 .

Table 7. Chemical analyses of flotation products .

\begin{tabular}{|l|l|l|}
\hline Constituents & \multicolumn{2}{|c|}{ Wt\% } \\
\hline & Concentrate & Tailings \\
\hline $\mathrm{SiO}_{2}$ & 55.71 & 73.85 \\
\hline $\mathrm{Al}_{2} \mathrm{O}_{3}$ & 29.35 & 12.94 \\
\hline $\mathrm{Fe}_{2} \mathrm{O}_{3}$ & 0.25 & 0.24 \\
\hline $\mathrm{MgO}$ & 0.01 & 0.02 \\
\hline $\mathrm{CaO}$ & 0.04 & 0.05 \\
\hline $\mathrm{K} 2 \mathrm{O}$ & 7.84 & 3.15 \\
\hline $\mathrm{Na}_{2} \mathrm{O}$ & 0.14 & 0.05 \\
\hline $\mathrm{TiO}_{2}$ & 0.11 & 0.14 \\
\hline $\mathrm{P}_{2} \mathrm{O}_{5}$ & 0.01 & 0.02 \\
\hline
\end{tabular}

From the above table it is observed that the assay of alumina has gone up from $21.4 \%$ to $29.35 \%$ and silica has come down from $63.62 \%$ to $55.71 \%$ in the concentrate. The effect of dodecylamine concentration at natural $\mathrm{pH}$ has also been studied. The results are shown in Fig.5. The weight of the concentrate has increased with increase in reagent concentration and the levels of $\mathrm{Al}_{2} \mathrm{O}_{3}$ vary between 26.2 to $29.5 \%$. It was observed that around $100 \mathrm{gm} /$ tonne of the reagent is sufficient for the flotation of minerals present in the ore. The improvement in the grade of pyrophyllite in respect of $\mathrm{Al}_{2} \mathrm{O}_{3}$ and curtailment of $\mathrm{SiO}_{2}$ contents by flotation technique has confirmed well to the recommended specification of refractory grade. The alkali content in the concentrate product however could not be brought down to the desired 
limit. Therefore, attempts need to be taken to optimally bring down the alkali content by resorting to suitable chemical techniques for which the efforts are afoot.

\section{CONCLUSION}

Pyrophyllite samples of Keonjhar district, Orissa are used in many industries. Of the three varieties, granular variety is in demand but because of less brightness, presence of coloured minerals and quartz, the utility is restricted. Hence the sample needs beneficiation. Beneficiation by flotation technique using dodecylamine as collector is found suitable to reduce the quartz content, coloured minerals and enhance the brightness of the product.

\section{Acknowledgements}

The authors are thankful to Director, IMMT, Bhubaneswar for his permission to

publish this paper. We are grateful to the authorities of Baliadihi mines for kindly providing the sample for the investigations.

\section{References}

[1] Hu, Y., Liu, X. and Xu Zhenghe. (2003) Minerals Engineering, Vol. 16, pp. 219- 227.

[2] Rath, B.D. (1998) The Explorer, Vol.17, pp. 81- 88.

[3] Chio, H.S. and Oh, J. (1965) J.Inst.Min.Metall., Japan, Vol. 21, pp.614.

[4] Smolik, J.J., Harman, E and Fuerstenau, D.W. (1966) Trans AIME, Vol. 235, pp.367.

[5] Zhao, S.M.; Wang, D.Z.; Hu,Y.H.; Liu, B.D. and Xu, J. (2003) Mineral Engineering, Vol. 16, pp. 1391- 1395.

[6] Cao, X.F.; Hu, Y.H. and Jiang, Y.R (2001) The Chinese J. Nonferrous Metals, Vol.11, No.4, pp. 693-696.

[7] Erdemoglu, M. and Sarikaya, M (2002) Mineral Engineering, Vol. 15, pp. 723- 725.

[8] Hussen, S.A.; Demirci, S. and Ozbayoglu, G. (1996) J. Colloid Interface Science, Vol.184, pp.535-541. 